\title{
Simian Foamy Viruses in Central and South America: A New World of Discovery
}

\author{
André F. Santos $\left.{ }^{1}{ }^{(}\right)$, Liliane T. F. Cavalcante ${ }^{1}$, Cláudia P. Muniz ${ }^{1}$, William M. Switzer ${ }^{2} \mathbb{C}$ and \\ Marcelo A. Soares 1,3,*(D) \\ 1 Departamento de Genética, Universidade Federal do Rio de Janeiro, Rio de Janeiro 21941-617, RJ, Brazil; \\ andre20@globo.com (A.F.S.); liliane.tavaresdefaria@gmail.com (L.T.F.C.); \\ claudia.muniz16@gmail.com (C.P.M.) \\ 2 Laboratory Branch, Division of HIV/AIDS Prevention, National Center for HIV/AIDS, Hepatitis, STD, \\ and TB Prevention, Centers for Disease Control and Prevention, Atlanta, GA 30329, USA; bis3@cdc.gov \\ 3 Programa de Oncovirologia, Instituto Nacional de Câncer, Riod e Janeiro, RJ 20231-050, RJ, Brazil \\ * Correspondence: masaores@inca.gov.br; Tel.: +55-21-3207-6591
}

Received: 30 September 2019; Accepted: 18 October 2019; Published: 20 October 2019

\begin{abstract}
Foamy viruses (FVs) are the only exogenous retrovirus to date known to infect neotropical primates (NPs). In the last decade, an increasing number of strains have been completely or partially sequenced, and molecular evolution analyses have identified an ancient co-speciation with their hosts. In this review, the improvement of diagnostic techniques that allowed the determination of a more accurate prevalence of simian FVs (SFVs) in captive and free-living NPs is discussed. Determination of DNA viral load in American primates indicates that oral tissues are the viral replicative site and that buccal swab collection can be an alternative to diagnose SFV infection in NPs. Finally, the transmission potential of NP SFVs to primate workers in zoos and primate centers of the Americas is examined.
\end{abstract}

Keywords: spumaretrovirus; new world primates; simian retrovirus

\section{Introduction}

Spumaretroviruses are complex, exogenous retroviruses in the Spumaretrovirinae subfamily known to infect different mammalian orders, such as nonhuman primates (NHPs), felines, bovines and equines [1]. In NHPs, spumaretroviruses are also called simian foamy viruses (SFVs). Despite being the only reported exogenous retrovirus known to infect neotropical primates (NPs), as first reported in 1973 [2], little is known about this viral infection. Recently published studies using improved molecular and serologic techniques for SFV diagnosis in NPs have shed light on the prevalence, transmission routes and zoonotic potential of these NP viruses.

\section{Neotropical Primates: Taxonomy and Evolution}

The word "primate" is derived from Latin primat that means prime or first rank. The Primates order has the third most abundant number of species among mammals, only behind Chiroptera (bats) and Rodentia (rodents) [3]. Although the exact number of species is still in discussion with constant changes in taxonomic classification, there are between 261 and 504 species described to date divided into 16 families and 79 genera [3,4]. Primates are distributed across four global regions: Latin America, mainland Africa, Madagascar, and Asia, covering 90 countries (Figure 1) [3]. Common features of the Primates order include a large brain in relation to the body size, accurate binocular color vision, opposable thumbs and a sophisticated social system. The common ancestor of the Primates order is estimated to have originated about 60-80 million years ago (MYA) based on evidence of small mammals adapted to live in trees and with the oldest fossil found in Africa [5]. 


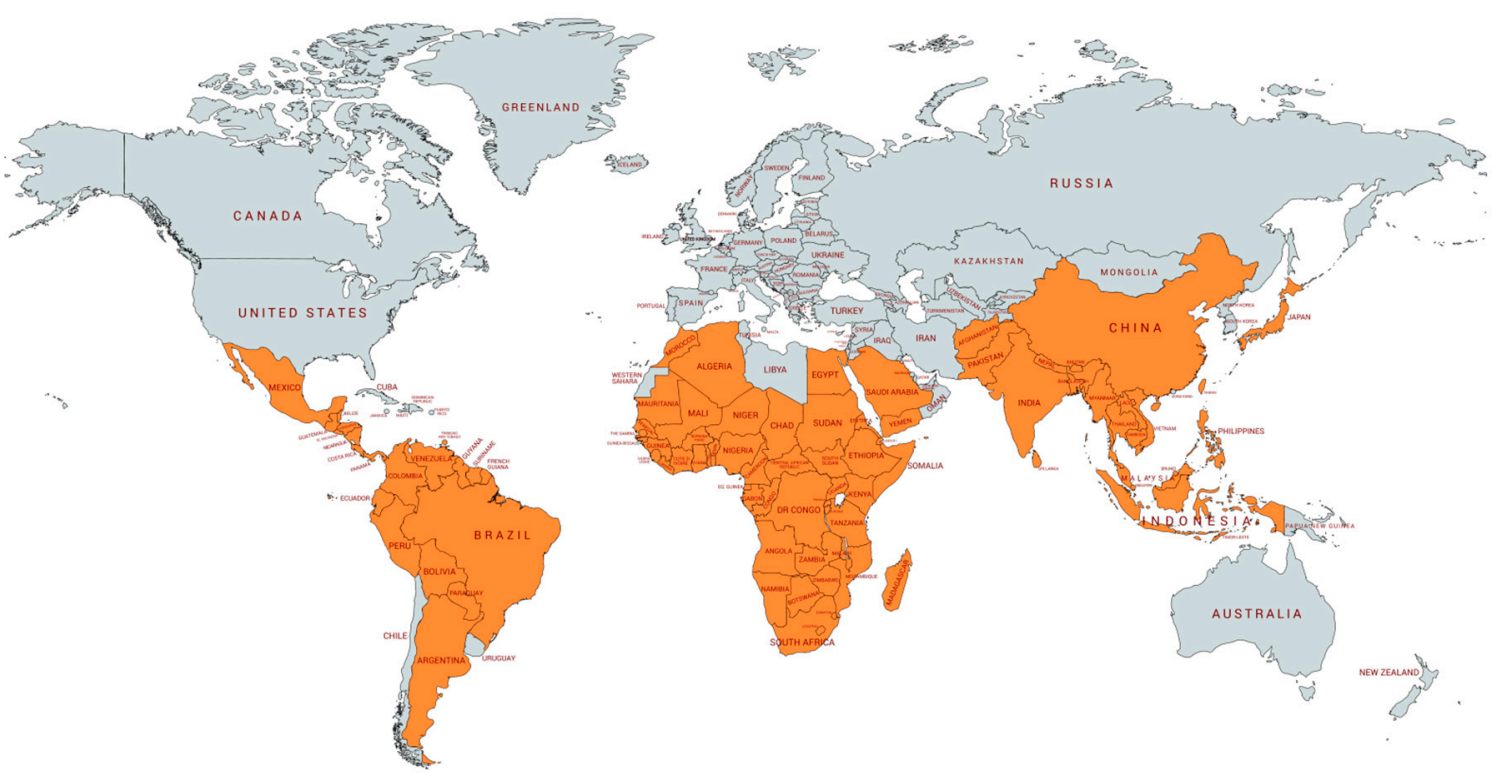

Figure 1. Global primate distribution. In orange, countries with native species of primates. Data were extracted from IUCN/SSC Primate Specialist group web site www.primate-sg.org/threat_primate_ habitat_country/ on August 15th. Graph art was generated using mapchart.net.

Primates radiated to five infraorders, of which the infraorder Simiiformes emerged about 36-50 MYA and is divided in the parvorders Catarrhini (Old World monkeys, great apes, gibbons, and humans) and Platyrrhini (neotropical monkeys). The parvorder Catarrhini consists of three families: Cercopithecidae, Hominidae and Hylobatidae. The Cercopithecidae family, also known as Old World primates (OWPs), is the largest family, with 32 genera and 138 species described living in Africa and Asia [4]. Examples of OWPs include the Macaca (macaques), Papio (baboons), Cercocebus (mangabeys) and Mandrillus (mandrills) genera, all primates lacking prehensile tails. The Hylobatidae family harbors Asian primates known as gibbons, considered small apes [6]. The Hylobatidae is considered a sister clade of the Hominidae family, composed of the great apes (the largest primate species) and includes four genera: Pongo (orangutan), Gorilla (gorilla), Pan (bonobo and chimpanzee) and Homo (human) [4].

The parvorder Platyrrhini, also known as neotropical primates (NPs), is composed of Latin American primates descendent from African Cercopithecidae primates that reached South America about 40 MYA [4,7]. The spread of NPs in South and Central America resulted in a broad radiation that permitted the occupation of a large range of biomes from Mexico to the Argentinian Patagonia, leading to a great diversity of morphology and body size [8]. NPs are small to mid-sized animals, ranging from the world's smallest primate pigmy marmoset (Cebuella pygmae; $14-16 \mathrm{~cm}$ in length) to the Southern muriqui (Brachyteles acrachnoides; $55-70 \mathrm{~cm}$ in length). Other unique features of Platyrrhini include a flat nose compared to OWPs (originating the name of the parvorder) and a prehensile tail. NPs also lack trichromatic vision, which is characteristic of OWPs [9]. In contrast to OWPs, most NP species constitute monogamous pairs, and provide extensive paternal care of young [10]. With respect to diet, NPs eat fruits, nuts, flowers, insects, bird eggs, spiders, and small mammals [11].

Platyrrhini is divided into three families (Atelidae, Cebidae, and Pitheciidae), 21 genera and at least 170 species according to recent molecular analyses [4], of which $42 \%$ are threatened (www. primate-sg.org/primate_diversity_by_region/). Since the 2000s, 19 novel species and subspecies have been described in the region, with the most recent being a new titi monkey species (Plecturocebus grovesi sp. nov.), described in 2019 [12]. 


\section{Diversity and Origin of SFVs in the Americas}

SFVs have been shown to naturally infect most nonhuman primates (NHPs), including NPs, OWPs, and prosimians $[13,14]$. For over 60 years of spumavirus study, most research focused on SFVs in OWPs. In 1973, the presence of a syncytium-forming virus was first detected in a spider monkey (Ateles sp.) brain culture, classified then as SFV-8 [2] and currently named SFVaxx after the revision of foamy virus nomenclature in 2018 [15]. The original classification using numbers was based on serologic neutralizing activity, with consecutive numbers used for those isolates with undetectable or weak neutralizing activity to known SFVs indicative of infection with a divergent variant. The current SFV classification uses a three-letter code for the host species name with the first letter of the host genus and the next two letters derived from the first two letters of the species or subspecies. If the species or subspecies is unknown, the letters " $x x^{\text {" }}$ are used. Hence, SFVaxx refers to SFV from an Ateles monkey for which the species is not known. In 1975, an SFV infecting capuchin monkeys (Cebus sp.) was isolated and called SFV-9 [16]. In 1976, another strain of SFV was isolated from red uacari (Cacajao rubicundus) lymphocytes in a co-culture with kidney cells from a nocturnal monkey (Aotus sp.) [17]. Early in the 1980s, a fourth neotropical SFV was characterized in skin explants of 46 healthy white-tufted marmosets (Callithrix jaccus) [18]. Not until 2007 was the complete genome of SFVaxx obtained, 34 years after it was first isolated [19]. In 2010, complete SFVssc and SFVcja genomes, which infect squirrel monkeys (Saimiri sciureus) and white-tufted marmosets (Callithrix jaccus), respectively, were reported [20].

While phylogenetic analysis of short polymerase $(\mathrm{pol})$ sequences demonstrated the co-evolution of SFVs with their NHP hosts [14], only one sequence from SFVaxx was available at the time to fully understand the evolutionary trajectory of SFVs in NPs. Phylogenetic analysis of the three complete SFV genomes from NPs with those from OWPs and a prosimian showed SFVs clustering into three major clades, reflecting the evolutionary split between NP (parvorder Platyrhini), OWP (parvorder Catarrhini), and prosimian (Strepsirrhini suborder) hosts [20]. More recently, complete SFV genomes were obtained from Sapajus xanthosternos, the yellow-breasted capuchin (SFVsxa), and Brachyteles arachnoides, the wooly spider monkey (SFVbar) [21,22]. Additionally, partial SFV pol and/or LTR/gag sequences (around 500-bp) were obtained from SFV strains infecting 20 different NP species from 10 genera, encompassing all three NP families (Table 1) [23-25]. Nonetheless, the complete or partial characterization of these few strains is still poor when compared to the wide diversity of NPs, with more than 150 species described. Furthermore, another 16 species from 11 NP genera had indirect evidence of foamy virus (FV) infection, characterized by diagnostic PCR, Western blot detection and/or detectable DNA viral load (VL) by quantitative PCR (qPCR) (Table 1). The size of the DNA fragments generated by these PCR techniques (192-bp) was, however, too small to enable robust phylogenetic inferences from those species, since this region is very conserved among the different strains and therefore has a low phylogenetic signal for resolution of related strains. 
Table 1. Simian foamy virus (SFV) diversity in neotropical primates revealed by virus detection and complete or partial genome characterization.

\begin{tabular}{|c|c|c|c|c|c|}
\hline Primate Family & Genus & Common Name & Complete Genome $^{1}$ & $\begin{array}{c}\text { Partial Genome } \\
(\text { LTR/gag and/or } \text { pol })^{1}\end{array}$ & $\begin{array}{c}\text { Diagnostic-PCR and/or qPCR } \\
\text { and/or WB Serology } 1\end{array}$ \\
\hline \multirow[t]{9}{*}{ Cebidae } & Aotus & owl monkey & \multirow{7}{*}{ SFVcja } & & \multirow{9}{*}{$\begin{array}{c}\text { SFVaaz, SFVatr, SFVani } \\
\text { SFVcgo } \\
\text { SFVcau } \\
\text { SFVcol } \\
\text { SFVlcp } \\
\text { SFVmhu } \\
\text { SFVsbi, SFVsfu, SFVsmi, } \\
\text { SFVsoe }\end{array}$} \\
\hline & Callimico & marmoset & & & \\
\hline & Callithrix & marmoset & & SFVcge & \\
\hline & Cebus & capuchin & & SFVcal & \\
\hline & Leontopithecus & tamarin & & SFVlro, SFVlcm & \\
\hline & Mico & marmoset & & & \\
\hline & Saguinus & tamarin & & & \\
\hline & Saimiri & squirrel monkey & SFVssc & SFVsbo, SFVsus & \\
\hline & Sapajus & capuchin & SFVsxa & SFVsap, SFVsfl, SFVsro & \\
\hline \multirow[t]{4}{*}{ Atelidae } & Alouatta & howler monkey & \multirow{4}{*}{$\begin{array}{l}\text { SFVaxx } \\
\text { SFVbar }\end{array}$} & $\begin{array}{l}\text { SFVabe, SFVaca, SFVagu, } \\
\text { SFVase }\end{array}$ & SFVapl \\
\hline & Ateles & spider monkey & & SFVage, SFVahy, SFVach & SFVafu, SFVapn \\
\hline & Brachyteles & wooly spider monkey & & & \\
\hline & Lagothrix & wooly monkey & & SFVlla & \\
\hline \multirow[t]{3}{*}{ Pitheciidae } & Cacajao & uakari & - & SFVcca, SFVcme & \multirow{3}{*}{ SFVcmo } \\
\hline & Callicebus & titi & - & & \\
\hline & Pithecia & saki & - & SFVppi & \\
\hline \multicolumn{6}{|c|}{$\begin{array}{l}1 \text { Species definition for SFV by primate genera: Aloutta: SFVabe (Alouatta belzebul), SFVaca (Alouatta caraya), SFVagu (Alouatta guariba), SFVase (Alouatta seniculus); SFVapl (Alouatta palliata); } \\
\text { Aotus: SFVaaz (Aotus azarae), SFVatr (Aotus trivirgatus), SFVani (Aotus nigriceps); Ateles: SFVage (Ateles geoffroyi), SFVahy (Ateles hybridus), SFVach (Ateles chamek), SFVafu (Ateles fusciceps), } \\
\text { SFVapn (Ateles paniscus), SFVaxx (Ateles sp.); Brachyteles: SFVbar (Brachyteles aracnoides); Cacajao: SFVcca (Cacajao calvus), SFVcme (Cacajao melanocephalus); Callicebus: SFVcmo (Callicebus } \\
\text { moloch); Callimico: SFVcgo (Callimico goeldii); Callithrix: SFVcau (Callithrix aurita), SFVcge (Callithrix geoffroyi), SFVcja (Callithrix jaccus); Cebus: SFVcal (Cebus albifrons), SFVcol (Cebus } \\
\text { olivaceus); Lagothrix: SFVlia (Lagothrix lagotricha) Leontopithecus: SFVlcm (Leontopithecus chrysomelas), SFVlcp (Leontopithecus chrysopygus), SFVlro (Leontopithecus rosalia); Mico: SFVmhu (Mico } \\
\text { humeralifer); Pithecia: SFVppi (Pithecia pithecia); Saguinus: SFVsbi (Saguinus bicolor), SFVsfu (Saguinus fuscicollis), SFVsmi (Saguinus midas), SFVsoe (Saguinus oedipus); Saimiri: SFVsbo (Saimiri } \\
\text { boliviensis), SFVssc (Saimiri sciureus), SFVsbo (Saimiri ustus); Sapajus: SFVsap (Sapajus apella), SFVsfl (Sapajus flavius), SFVsro (Sapajus robustus), SFVsxa (Sapajus xanthosternos). }\end{array}$} \\
\hline
\end{tabular}


Phylogenetic analysis of the genetic sequences of NP SFV isolates has allowed for the determination of their evolutionary history, which shows distinct evolutionary lineages. Furthermore, genetic characterization of endogenous FVs integrated into mammals, reptiles, amphibians and fish [14,26-31] has permitted elucidation of the genetic relationships between exogenous and endogenous FVs, revealing strong evidence of an ancient co-speciation of FVs with their hosts since the origin of marine vertebrates around 500 MYA [27]. The co-speciation hypothesis of SFVs with their primate hosts has also been demonstrated in OWPs and NPs at the family, genus and species levels occurring around 43 MYA [24,25,32]. The phylogeny of NP SFVs also reflects the evolutionary relationships of their hosts, but with some exceptions. For example, SFVs from monkeys in the Pithecidae family (Pithecia, Cacajao, Chiropotes) are not monophyletic as expected with co-evolution and SFV pol sequences from Saimiri are paraphyletic to those from monkeys in the Cebidae family instead of being sister taxa in accordance with the co-evolutionary hypothesis (Figure 2). These unexpected phylogenetic relationships may result from only short sequences being analyzed or from cross-species infections, as further discussed below.

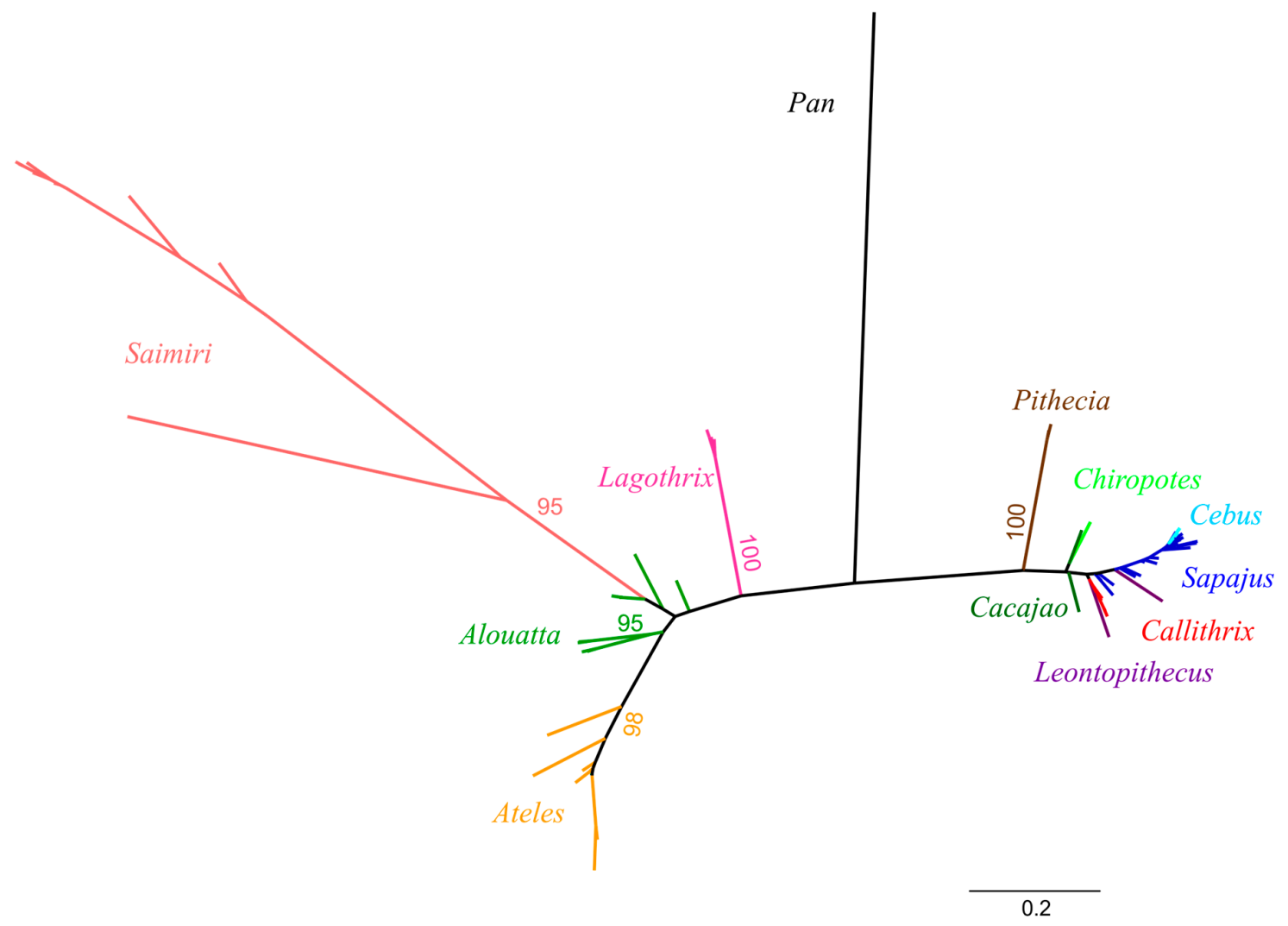

Figure 2. Phylogenetic relationships of simian foamy viruses from neotropical primates (NPs). Unrooted tree inferred by maximum likelihood analysis of an alignment of 411 nucleotides of partial polymerase sequences with 1000 bootstrap replicates. Different NP genera and bootstrap values are indicated by distinct colors. Distance bar is shown at the bottom.

Comparison of complete SFV genomes among primate hosts revealed some interesting features (Figure 3). For example, the mean size of the pol gene is highly conserved among SFVs infecting OWPs and NPs (average of 3435-bp and 3436-bp, respectively) [21]. Similarly, the envelope (env) gene lengths are also comparable with a mean size of 2949-bp in NP SFVs and 2962-bp in OWP SFVs. The length of these two genes also appears to be conserved in feline and equine FVs. The exception is the bovine FV pol gene, which is 3660-bp in length [21]. The size of the gag gene coding for the group specific antigen is conserved within both NP (range of 1817-2071-bp) and OWP SFVs (range of 1872-1974-bp) [21,22,33]. The exception is SFVssc, which has the shortest gag gene (1716-bp) of all 
SFVs described to date. The long terminal repeat (LTR) region has a mean length of 1696-bp among OWP SFVs, with the longest LTR in SFVs infecting a pileated gibbon (SFVhpi), at 2074-bp [21,33], while an SFV infecting Cebidae has the shortest LTR among FVs (1061-1080-bp). SFVaxx has LTRs ranging from 1129-bp (SFVbar) to 1251-bp (SFVasp) in length [21,22]. Whether gene or LTR length differences among SFVs affect their biological functions remains to be elucidated.

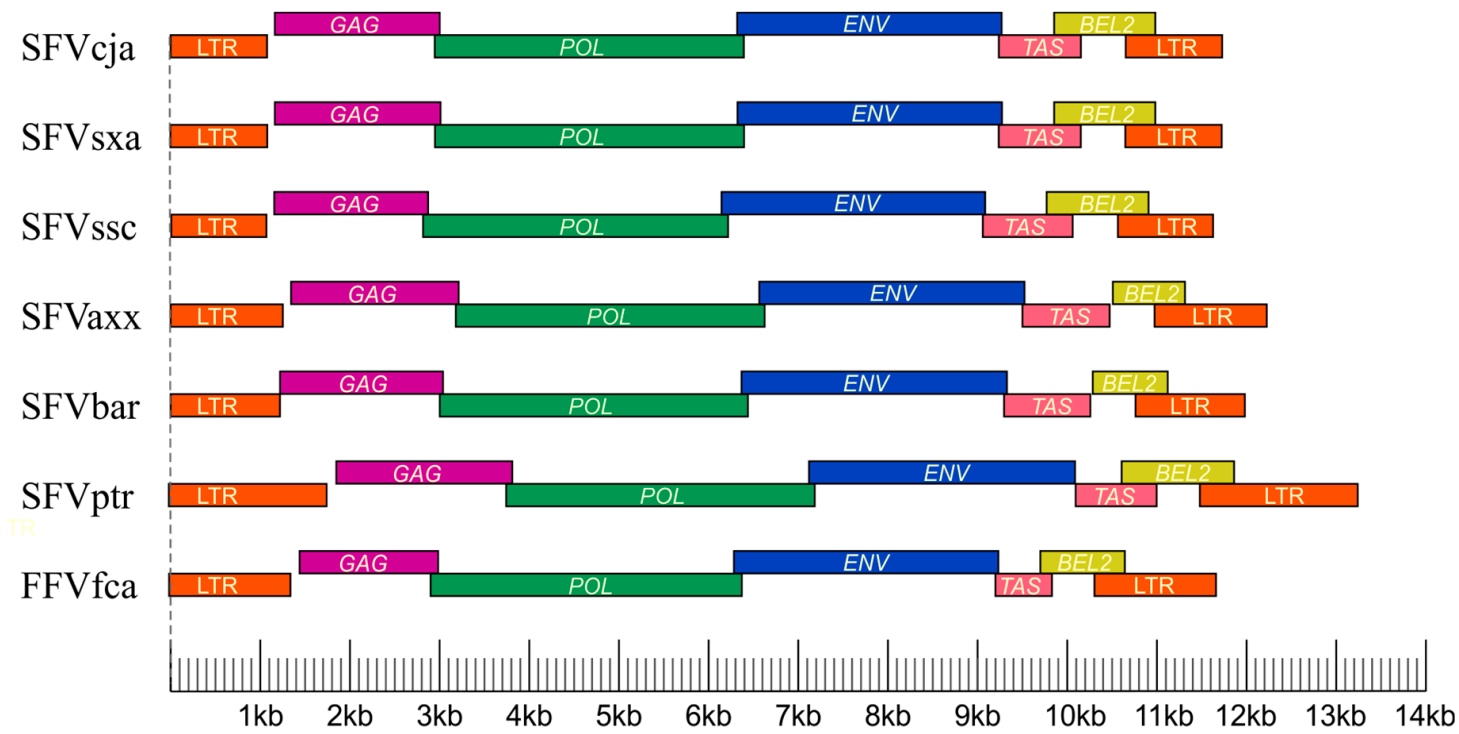

Figure 3. Structural organization of complete simian foamy virus (SFV) and feline foamy virus (FFV) genomes. SFVcja (Callithrix jaccus), SFVsxa (Sapajus xanthosternos), SFVssc (Saimiri sciureus), SFVaxx (Ateles sp.), SFVbar (Brachyteles aracnoides), SFVptr (Pan troglodytes), FFVfca (Feline catus). LTR, long terminal repeat; GAG, group specific antigen, POL, polymerase; ENV, envelope; TAS, transcriptional activator; BEL2, between the ENV and LTR.

\section{NP SFV Prevalence and Viral Detection Methodologies}

Very little is known about the prevalence of SFV in wild NP populations, while studies of captive animals are relatively common (Table 2). A seminal study in 1975 with Ateles sp. (spider monkeys) determined that $61 \%$ of specimens had antibodies against SFVaxx [16]. Another study conducted in the 1980s with 90 marmosets (Callithrix jaccus and Saguinus sp.) living in a colony in the United States (U.S.), found a 54\% SFV seroprevalence only in Callithrix specimens [18]. However, these studies were performed using in-house serological assays that were not validated and standardized, and therefore the reported SFV serological prevalence may have been overestimated by the lack of specificity of the test and/or possible cross-reactivity.

Table 2. Simian foamy virus prevalence in neotropical primates.

\begin{tabular}{cccc}
\hline Study & Methodology & Sites & Prevalence \\
\hline Hooks, 1975 [2] & Serology & Colony & $61 \%$ \\
Marczynska et al., 1981 [18] & Serology & Colony & $54 \%$ \\
Muniz et al., 2013 [23] & Diag. PCR ${ }^{1}$ & Brazilian zoo and primatology center & $23 \%$ \\
& & Wild primates & $29 \%$ \\
Ghersi et al., 2015 [25] & Serology and & Peruvian and US zoos & $45-47 \%$ \\
& Diag. PCR & Peruvian rescue center & $19 \%$ \\
Muniz et al., 2015 [24] & Serology and & Illegal trade market & $51 \%$ \\
\hline
\end{tabular}

${ }^{1}$ Diagnostic PCR. 
Decades later in 2013, a large study examined 332 NP samples from 15 genera using molecular testing to detect 192-bp pol NP SFV sequences in peripheral blood mononuclear cells (PBMCs), including - for the first time-samples collected from wild monkeys [23]. The PCR assay used in this study had a $100 \%$ sensitivity using PBMC specimens from Western blot (WB)-positive monkeys from seven NP genera (Alouatta, Aotus, Ateles, Cacajao, Callithrix, Cebus, and Pithecia), except for Saimiri specimens, with four PCR-positive specimens being WB-negative [34]. The WB used combined antigens from extracts of CfTh2 cells infected with two NP SFV isolates from Callithrix jaccus (SFVcja) and Ateles sp. (SFVaxx), representing two out of the three NP families, and had shown sensitivity and specificity both $>94 \%$ using $>100 \mathrm{SFV}+$ and SFV- NP specimens [25]. Muniz et al. showed that SFV prevalence among captive specimens was $23 \%$ (61/267) versus $29 \%(19 / 65)$ in wild NPs [23]. The molecular prevalence found in this study is lower than that described for African OWP SFVs in wild monkeys (60-100\%), including mandrills (Mandrillus sphinx), red colobus monkeys (Piliocolobus badius badius), baboons (Papio cynocephalus) and chimpanzees (Pan troglodytes) [35-38]. In comparison, the molecular prevalence of SFV in captive Asian macaques is 39\% among rhesus macaque (Macaca mulata) [39], while a seroprevalence of $64-94 \%$ has been reported in captive cynomolgus macaque (Macaca fascicularis) [40]. The lower SFV prevalence in NPs may reflect a high number of specimens from juveniles, since SFV seroprevalence has been shown to be associated with age. For instance, in a study of a colony of tonkean macaques (Macaca tonkeana), SFV seroprevalence was shown to be lower in infants (5\%), intermediate in sub-adults $(44 \%)$ and high in adults $(89 \%)$ [41]. The same age and seroprevalence relationship has been observed in baboons and cynomolgus macaques $[1,40,42]$. However, no age of specimens was available in Ref. [23], since that was a study conducted with retrospective samples.

In 2015, a new study estimated the SFV prevalence among Peruvian primates in zoos, rescue centers and the illegal trade market using both molecular and serological assays [25]. The seroprevalence of SFV in NPs from Peruvian zoos using both enzyme immunoassay (EIA) and Western blot (WB) was higher $(47 \%)$ than those in rescue centers of free-living primates $(19 \% ; p=0.001)$ and similar to those reported in NPs from U.S. zoos (45\%). Noteworthy was the SFV prevalence of $43 \%$ in Peruvian zoos and $22 \%$ in rescue centers in Lagothrix lagothicha (wooly monkey), indicating an increased SFV infection in captivity. The lower prevalence in rescue centers could reflect testing of younger animals. Overall, the WB assay in that study showed a total prevalence of $78 \%$, higher than those of the diagnostic PCR assay $(19 \%)$ and for a PCR test that detected a 495-bp pol sequence $(26 \%)$, indicating that WB more accurately detects previous or current SFV infection. The low efficiency of the diagnostic PCR method could be explained by the high genetic variability of NP SFVs. The pol genetic diversity between strains of SFV infecting genera within the same primate family is around $12 \%$ in the Cebidae and $31 \%$ in the Atelidae families. In contrast, a higher pol divergence (41\%) occurs between SFV from the Atelidae and Cebidae [23]. The lower sensitivity of the PCR assay could also be explained by the low DNA proviral load (pVL) of NP SFVs in blood cells, with an average of 800 SFV copies/106 cells reported [43,44], very similar to that found in OWPs $[45,46]$. Furthermore, these findings suggest that SFV does not expand to significant levels in this compartment [46,47].

Another study in 2015 compared the serological and molecular prevalence of NP SFV at the Rio de Janeiro Zoo and the Center of Primatology of Rio de Janeiro state, confirming that WB is more sensitive for detecting SFV infection in NPs [24]. However, as some WB-seronegative animals in the study were PCR-positive, the use of both techniques for SFV detection is needed for epidemiologic studies. Monkeys testing positive with either or both tests would then be considered SFV-positive. In this study, the NP SFV prevalence was similar to that found in Peru, with a WB prevalence of $43 \%$ and a molecular prevalence of $29 \%$ in captive animals. Of the 140 specimens analyzed, $51 \%$ were positive in at least one test. Although serology in these recent studies was shown to be more sensitive for SFV detection, preparation of large amounts of antigens used in the serologic assays may be costly and is dependent on the laboratory having biosafety facilities and equipment for cultivating FV strains in cell culture [24,25]. Good alternatives to that limitation include cloning of SFV gag genes and expressing them in bacterial 
systems, or the use of synthesized peptides from gag gene sequences to detect antibodies, which have been used in feline foamy virus (FFV) and SFV research $[48,49]$. More recently, a new study developed a real-time PCR (qPCR) methodology to diagnose and measure SFV DNA pVL in NPs with a high sensitivity and specificity [43]. Of animals with detectable SFV DNA pVL, 90-96\% were also WB-positive. NP SFV prevalence using the different methodologies is summarized in Table 2.

An important concern for detecting SFV in the blood of NPs is the small size of these animals, which limits the amount of blood collected. Consequently, there is typically only low amounts of genomic DNA available to be used for diagnostic PCR [23,24]. Considering this, qPCR can be used as a simpler alternative to SFV WB detection with the same sensitivity but using less DNA. Another alternative is the use of buccal swabs for PCR detection of NP SFVs. In addition to being a less invasive collection method, SFV replication is higher in the oral cavity of OWPs [45,50], which should increase the sensitivity of detecting SFV infection by using molecular methods [51,52]. For NPs, the SFV DNA $\mathrm{pVL}$ found in oral tissues ranges between $20-142$ million copies $/ 10^{6}$ cells [43], which is higher than that reported for SFV-infected rhesus macaques (Macaca mulatta) using salivary gland, tonsil and tongue specimens (500-100,000 SFV copies $/ 10^{6}$ cells) [46]. A recent study showed that the DNA pVL found in oral tissues of NPs with matching PBMC samples was up to 8000 copies/10 $10^{6}$ cells higher than those observed in blood cells, showing that oral tissues are better specimens for SFV detection [43]. The authors of that NP study also showed that the DNA pVL in PBMC is a proxy for the detection of proviral DNA in PBMC by nested PCR with qPCR again being more sensitive. However, only $45 \%$ of NPs in that study had SFV detected in oral tissues, which could underestimate the true prevalence in NPs if only buccal swabs are used for diagnosis [43].

\section{NP SFV Epidemiology and Transmission}

In OWPs, SFV proviral DNA has been found in many tissues and cell types, including in oral-respiratory tissues and peripheral blood cells $[47,53]$. Nonetheless, viral expression and replication appear to be restricted to the oral mucosa, as studies have shown high levels of viral RNA only at this site [1,47]. It has also been reported that oral mucosa epithelial cells act as a virus reservoir [50]. Thus, scratches, bites and grooming constitute the main routes of horizontal OWP SFV transmission, mainly via parental care and aggressive behavior in territorial and sexual partner disputes [1].

For NPs, SFVs have been molecularly detected in liver specimens [23], oral tissues [43] and peripheral blood cells $[23-25,43]$. The SFV DNA proviral load (pVL) in oral mucosa is similar for NPs $[43,44]$ and OWPs $[45,46]$, indicating this compartment as a virus reservoir for FV infecting primates in general. The higher SFV DNA pVL found in oral tissues of SFV-infected NPs is compatible with horizontal transmission via contact with saliva in biting or grooming, as described for OWPs $[1,50]$. However, studies in NPs have not yet been conducted to determine SFV RNA levels in these compartments and their correlation with transmission. Since SFV isolates have been obtained from oral swabs of NPs, it would not be surprising that comparable SFV RNA levels are found in NPs as in OWPs [45].

Murray et al. proposed a model in which SFV primary infection occurs in blood and migratory cells, such as macrophages or leukocytes, which carry the virus to the basal epithelium of oropharyngeal tissues, with subsequent FV replication in differentiated epithelial cells [50]. A cynomolgus macaque (Macaca fascicularis) that was infected by SFV after a controlled blood transfusion from an SFV-infected donor macaque showed detectable DNA VLs in saliva 29 weeks after infection and detectable RNA VLs after 39 weeks [54]. In this scenario, it may take months for a newly infected animal to become capable of transmitting SFV. This model could explain why only $45 \%$ of SFV-infected NPs had DNA VL detectable in oral tissues [43]. Similar results were observed in free-ranging rhesus macaques (Macaca mulatta), of which about 30\% of SFV-positive animals did not have detectable RNA VLs in saliva [45]. The RNA VLs in this study also correlated with the age of the macaques, with older monkeys having higher SFV RNA levels [45]. 
SFVs can also be transmitted vertically but studies have been limited to small numbers of species. Blasse et al. showed that mother-to-offspring transmission of SFV is frequent among Western chimpanzees (Pan troglodytes verus) [55]. However, vertical transmission was rare in a study of captive Macaca tonkeana [41]. Even less is known about vertical transmission in NPs. A five month-old Chiropotes infant in quarantine was SFV-positive by both WB and pol-integrase PCR testing, indicating a possible vertical transmission [24]. However, samples from the mother were not available for testing to confirm this hypothesis, as the infant was from a rescue center. Studies of specimens collected in utero, perinatally, and from breast milk are needed to better understand the risks of vertical transmission of SFV.

Sexual transmission occurs for animals infected with other retroviruses, like primate lentivirus (SIV), but is rare [56,57]. However, little is known about the potential for sexual transmission for SFV. Differences in the NP SFV prevalence in males and females have not been observed, suggesting that if sexual transmission occurs it is equally likely from male to female and vice versa [23-25]. Differences in the SFV prevalence among different age groups of NPs have been reported, suggesting that horizontal transmission is likely more common than vertical transmission. Ghersi et al. found that the SFV prevalence increased with age among captive NPs in Peru, with $0 \%$ in infants, $30-50 \%$ in juveniles, $50-58 \%$ in sub-adults and 55-64\% in adults [25]. In NPs from Peruvian rescue centers in that study, the SFV seroprevalence was higher in adults (32\%) than in juveniles $(17 \%)$. These findings are congruent with the SFV prevalence found in different age groups of OWPs $[1,40,41]$. However, Muniz et al. did not find a significant difference in SFV prevalence between juveniles (73\%) and adults $(87 \%)$ in vivaria in Brazil [24]. This SFV prevalence disparity may reflect a more confined environment of the vivaria in Brazil, which can increase the stress of the animals and, consequently, viral transmission. Another explanation could be different transmission rates by primate species. For example, when SFV results of Sapajus were analyzed separately, as they represented one third of the samples in that study, infected NPs were on average 6.8 years older than the uninfected NPs [24]. Additional studies with NPs from other countries, environments, and with more species will help to better define NP SFV prevalence by age. Nonetheless, the finding of high VLs in the oral mucosa and in older animals, and the increased SFV prevalence in older monkeys, suggests that horizontal transmission likely occurs via aggressive behaviors, such as biting, as monkeys become adults [1].

Similar to SFV-infected OWPs, evidence of pathogenicity has not been reported in SFV-infected NPs, though systematic studies have not been conducted for both parvorders. In rhesus macaques, SIV and SFV co-infection was reported to accelerate immunodeficiency related death (75\% of deaths in 39 weeks) in comparison to those infected with only SIV (37\% of deaths in 39 weeks), suggesting SFV co-infection may affect pathogenicity [58]. Similar co-infection studies in SFV-infected NPs have not been done.

\section{SFV Cross-Species Transmission}

Episodes of SFV transmission between NP species seems rare with only a few reported cases. A captive yellow-breasted capuchin (Sapajus xanthosternos) of the Cebidae family was found to be infected with an SFV that was phylogenetically more similar with an SFV from a spider monkey (Ateles species) of the Atelidae family [23]. Most likely, this cross-species transmission occurred while these monkeys were in captivity, since both primate species are not sympatric in Brazil. Sapajus xanthosternos are naturally found in the Caatinga forest of northeastern Brazil, while all species of Ateles inhabit the Amazon forest in northern Brazil. Phylogenetic analysis has also shown divergent SFV in Leontopithecus (tamarins) that do not cluster together, as would be expected under the co-evolution of SFV and host hypothesis, indicating at least one cross-species transmission in captivity [24]. Studies with free-living Leontopithecus will have to elucidate this finding.

Ancient cross-species and cross-genus SFV transmission may also have occurred in NPs and could explain the extant phylogenetic relations observed for SFVs in squirrel monkeys (Saimiri sp.) in the Cebidae family $[14,23,25]$. Squirrel monkey SFVs are more similar to those from monkeys in 
the Atelidae family (Figure 3) instead of the Cebine family (capuchins) as expected with a stable co-speciation history. Phylogenetic dating suggests that this cross-species transmission may have occurred at least 17 MYA with one or more SFV lineages not yet characterized, or possibly from the Aotus genus [25]. SFV cross-species transmissions have also been described for OWPs and appear to be equally infrequent $[36,59]$.

To date, all persistent SFV infections detected in humans with documented viral nucleic acids originated by zoonotic transmissions of SFV infecting OWPs [60-64]. Cases of zoonotic transmission have been reported among individuals with exposure to nonhuman primates (NHPs), including veterinarians, keepers, biologists, researchers, and pet owners. Butchers and hunters can also be infected with SFV as OWP hunting and meat consumption is common in African villages and indigenous communities [65]. These workers and hunters have been infected with many different divergent OWP SFVs, including macaques, African green monkeys, chimpanzees, gorillas, mandrills, colobus monkeys, and various Cercopithecus species [63,66-69]. Interestingly, studies have shown that between 18 and $36 \%$ of individuals who were severely bitten or injured from hunting wild chimpanzees and gorillas in Cameroon and Gabon were SFV-positive [60,70], further supporting bites as the major transmission route. Longitudinal studies of persons infected with OWP SFVs have yet to show strong evidence of diseases associated with their zoonotic infections [57-60]. One recent case-control study reported potential hematological abnormalities in apparently healthy SFV-infected persons from Cameroon [66]. More systematic longitudinal studies are required to investigate SFV disease associations, including in persons co-infected with other retroviruses such as human immunodeficiency and human T-cell leukemia viruses.

In contrast to OWPs, the potential for zoonotic transmission of NP SFVs to humans is less clear. A first study evaluated the presence of SFV among 116 primatologists, of which 69 were occupationally exposed to NPs [44]. While $12 \%(8 / 69)$ of the primatologists were positive for NP SFV by WB, no viral DNA was detected in the blood of these individuals, suggestive of exposure but not persistent infection or latent infection. Only four of the eight SFV-seropositive individuals reported accidents with NPs such as bites, scratches and injuries with contaminated sharp instruments. The other four workers reported contact with body fluids, but not parenterally, suggesting that contact with animal fluids without parenteral exposure may be sufficient for viral infection [44].

More recently, a study of persons occupationally exposed to SFV-infected NPs at a zoo and a primatology center in Brazil was reported. In this study, whole blood and oral swab samples were obtained from 56 individuals over three years (2011, 2012/2013 and 2014) [67]. A serological prevalence of $19 \%$ was found for NP anti-SFV antibodies, while—-similar to the initial study described above-viral DNA was not detected in any of the sampled compartments. As issues related to the presence of PCR inhibitors in the DNA preparations were considered, the authors used different methods to clean the DNA from potential inhibitors, including the use of the OneStep PCR inhibitor removal kit (Zymo Research, Irvine, CA, USA) or of general column-based PCR purification kits after DNA extraction. However, even those measures failed to provide PCR-positive samples. Of the 12 SFV-seroreactive workers, 11 reported bites, scratches and/or direct contact with body fluids from NPs. Interestingly, for some of the workers more recently exposed to infected animals, a clearance of SFV antibodies was detected two years later compared to previous collection time points. WB-negative workers in this study reported contact with NPs for an average of 12 years, while the WB-positive workers reported NP contact for an average of only three years.

Combined, these findings in persons exposed to NPs suggest possible control of SFV infection and antibody clearance, in contrast to human infection with OWP SFV. In these NP exposure cases, it is not known whether the virus has been truly eliminated from the body or if it is still present in another body compartment or reservoir. Additional follow-up testing of these workers and additional studies of persons exposed to NPs will help to elucidate the potential for zoonotic transmission of NP SFVs to humans. Exposure to NPs in Brazil can be frequent in forest parks and in large urban centers where primates have been observed feeding on household waste [68]. Evidence for disease in these workers 
with SFV-reactive serology results was not reported and clear evidence of disease associations has not been found in persons infected with OWP SFVs [64,68].

Like OWP SFVs, studies have documented that different human cells can be infected with NP SFVs, including strains of SFVaxx and SFVssc, but the cell tropism was distinct between strains. SFVaxx infected HT1080 (fibrosarcoma), MDA (mammary adenocarcinoma) and C33A (cervical carcinoma), but not AGS (adenocarcinoma), LN (lymphoblastoid) and LoVo (adenocarcinoma), while SFVssc infected only HT1080 [44]. Another study showed that the human TRIM5 $\alpha$ did not affect the replication of SFVcja and SFVaxx [69], but restricted the replication of SFVssc [20]. These latter findings may help to explain the seroreactive but PCR-negative results in humans exposed to NP SFVs.

\section{Perspectives}

While considerable progress has been made in recent years to better understand the epidemiology and evolutionary history of NP SFVs, more research is needed. Additional SFV genomes should be sequenced, with emphasis on those infecting species from the Pitheciidae family (titi, saki and uacari monkeys) and the Aotus genus (owl monkeys), in order to clarify the evolutionary relationships of SFV among NPs, especially the unusual relationships of SFV that infect squirrel monkeys (Saimiri sp). Studies published to date with NPs have used a large number of specimens of various captive genera and species, but few specimens of each species. Future work should focus on studies of the viral epidemiology of wild NPs, with a reasonable number of specimens per species. RNA VL in oral tissues needs to be determined, as well as which tissues are targeted by SFV infection in NPs. Follow-up studies of workers with direct or indirect contact with NPs should continue to clarify whether SFV infection is resolved or if the virus persists in certain cells or body compartments. Additional studies of persons naturally exposed to NPs and their SFV infections are needed to define zoonotic risks for these viruses.

Author Contributions: All authors contributed equally to this paper with the conception and design of the paper, literature review and analysis, drafting, critical revision and editing, and approval of the final version.

Funding: This research received no external funding.

Acknowledgments: Use of trade names is for identification only and does not imply endorsement by the U.S. Department of Health and Human Services, the Public Health Service, or the Centers for Disease Control and Prevention (CDC). The findings and conclusions in this report are those of the authors and do not necessarily represent the views of the $C D C$, or any of the authors' affiliated institutions.).

Conflicts of Interest: The authors declare no conflict of interest.

\section{References}

1. Murray, S.M.; Linial, M.L. Foamy virus infection in primates. J. Med. Primatol. 2006, 35, 225-235. [CrossRef] [PubMed]

2. Hooks, J.J.; Gibbs, C.J., Jr.; Chou, S.; Howk, R.; Lewis, M.; Gajdusek, D.C. Isolation of a new simian foamy virus from a spider monkey brain culture. Infect. Immun. 1973, 8, 804-813. [PubMed]

3. Estrada, A.; Garber, P.A.; Rylands, A.B.; Roos, C.; Fernandez-Duque, E.; Di Fiore, A.; Nekaris, K.A.; Nijman, V.; Heymann, E.W.; Lambert, J.E.; et al. Impending extinction crisis of the world's primates: Why primates matter. Sci. Adv. 2017, 3, e1600946. [CrossRef] [PubMed]

4. Perelman, P.; Johnson, W.E.; Roos, C.; Seuanez, H.N.; Horvath, J.E.; Moreira, M.A.; Kessing, B.; Pontius, J.; Roelke, M.; Rumpler, Y.; et al. A molecular phylogeny of living primates. PLoS Genet. 2011, 7, e1001342. [CrossRef] [PubMed]

5. Goodman, M.; Porter, C.A.; Czelusniak, J.; Page, S.L.; Schneider, H.; Shoshani, J.; Gunnell, G.; Groves, C.P. Toward a phylogenetic classification of Primates based on DNA evidence complemented by fossil evidence. Mol. Phylogenet. Evol. 1998, 9, 585-598. [CrossRef] [PubMed]

6. Brandon-Jones, D.; Eudey, A.A.; Geissmann, T.; Groves, C.P.; Melnick, D.J.; Morales, J.C.; Shekelle, M.; Stewart, C.-B. Asian Primate classification. Int. J. Primatol. 2004, 25, 67. [CrossRef] 
7. Perez, S.I.; Tejedor, M.F.; Novo, N.M.; Aristide, L. Divergence times and the evolutionary radiation of new world monkeys (platyrrhini, primates): An analysis of fossil and molecular data. PLoS ONE 2013, 8, e68029. [CrossRef] [PubMed]

8. Rosenberger, A.L. Evolution of feeding niches in New World monkeys. Am. J. Phys. Anthropol. 1992, 88, 525-562. [CrossRef]

9. Carroll, S.B. The Making of the Fittest: DNA and the Ultimate Forensic Record of Evolution, 1st ed.; W.W. Norton \& Co.: New York, NY, USA, 2006; p. 301.

10. Garber, P.A.; Leigh, S.R. Ontogenetic variation in small-bodied New World primates: Implications for patterns of reproduction and infant care. Folia Primatol. 1997, 68, 1-22. [CrossRef]

11. Amato, K.R.; Martinez-Mota, R.; Righini, N.; Raguet-Schofield, M.; Corcione, F.P.; Marini, E.; Humphrey, G.; Gogul, G.; Gaffney, J.; Lovelace, E.; et al. Phylogenetic and ecological factors impact the gut microbiota of two Neotropical primate species. Oecologia 2016, 180, 717-733. [CrossRef]

12. Boubli, J.P.; Byrne, H.; da Silva, M.N.F.; Silva-Junior, J.; Costa Araujo, R.; Bertuol, F.; Goncalves, J.; de Melo, F.R.; Rylands, A.B.; Mittermeier, R.A.; et al. On a new species of titi monkey (Primates: Plecturocebus Byrne et al., 2016), from Alta Floresta, southern Amazon, Brazil. Mol. Phylogenet. Evol. 2019, 132, 117-137. [CrossRef] [PubMed]

13. Peeters, M.; D'Arc, M.; Delaporte, E. Origin and diversity of human retroviruses. AIDS Rev. 2014, 16, $23-34$. [PubMed]

14. Katzourakis, A.; Aiewsakun, P.; Jia, H.; Wolfe, N.D.; LeBreton, M.; Yoder, A.D.; Switzer, W.M. Discovery of prosimian and afrotherian foamy viruses and potential cross species transmissions amidst stable and ancient mammalian co-evolution. Retrovirology 2014, 11, 61. [CrossRef] [PubMed]

15. Khan, A.S.; Bodem, J.; Buseyne, F.; Gessain, A.; Johnson, W.; Kuhn, J.H.; Kuzmak, J.; Lindemann, D.; Linial, M.L.; Lochelt, M.; et al. Spumaretroviruses: Updated taxonomy and nomenclature. Virology 2018, 516, 158-164. [CrossRef]

16. Hooks, J.J.; Gibbs, C.J., Jr. The foamy viruses. Bacteriol. Rev. 1975, 39, 169-185.

17. Barahona, H.; Garcia, F.G.; Melendez, L.V.; King, N.W.; Ingalls, J.K. Isolation and characterization of lymphocyte associated foamy virus from a red uakari monkey (Cacajao rubicundus). J. Med. Primatol. 1976, 5, 253-265. [CrossRef]

18. Marczynska, B.; Jones, C.J.; Wolfe, L.G. Syncytium-forming virus of common marmosets (Callithrix jacchus jacchus). Infect. Immun. 1981, 31, 1261-1269.

19. Thumer, L.; Rethwilm, A.; Holmes, E.C.; Bodem, J. The complete nucleotide sequence of a New World simian foamy virus. Virology 2007, 369, 191-197. [CrossRef]

20. Pacheco, B.; Finzi, A.; McGee-Estrada, K.; Sodroski, J. Species-specific inhibition of foamy viruses from South American monkeys by New World Monkey TRIM5\{alpha\} proteins. J. Virol. 2010, 84, 4095-4099. [CrossRef]

21. Troncoso, L.L.; Muniz, C.P.; Siqueira, J.D.; Curty, G.; Schrago, C.G.; Augusto, A.; Fedullo, L.; Soares, M.A.; Santos, A.F. Characterization and comparative analysis of a simian foamy virus complete genome isolated from Brazilian capuchin monkeys. Virus Res. 2015, 208, 1-6. [CrossRef]

22. Muniz, C.P.; Cavalcante, L.T.F.; Dudley, D.M.; Pissinatti, A.; O'Connor, D.H.; Santos, A.F.; Soares, M.A. First complete genome sequence of a simian foamy virus infecting the neotropical primate brachyteles arachnoides. Microbiol. Resour. Announc. 2018, 7, 2. [CrossRef] [PubMed]

23. Muniz, C.P.; Troncoso, L.L.; Moreira, M.A.; Soares, E.A.; Pissinatti, A.; Bonvicino, C.R.; Seuanez, H.N.; Sharma, B.; Jia, H.; Shankar, A.; et al. Identification and characterization of highly divergent simian foamy viruses in a wide range of new world primates from Brazil. PLoS ONE 2013, 8, e67568. [CrossRef] [PubMed]

24. Muniz, C.P.; Jia, H.; Shankar, A.; Troncoso, L.L.; Augusto, A.M.; Farias, E.; Pissinatti, A.; Fedullo, L.P.; Santos, A.F.; Soares, M.A.; et al. An expanded search for simian foamy viruses (SFV) in Brazilian New World primates identifies novel SFV lineages and host age-related infections. Retrovirology 2015, 12, 94. [CrossRef] [PubMed]

25. Ghersi, B.M.; Jia, H.; Aiewsakun, P.; Katzourakis, A.; Mendoza, P.; Bausch, D.G.; Kasper, M.R.; Montgomery, J.M.; Switzer, W.M. Wide distribution and ancient evolutionary history of simian foamy viruses in New World primates. Retrovirology 2015, 12, 89. [CrossRef] [PubMed]

26. Han, G.Z.; Worobey, M. Endogenous viral sequences from the Cape golden mole (Chrysochloris asiatica) reveal the presence of foamy viruses in all major placental mammal clades. PLoS ONE 2014, 9, e97931. [CrossRef] [PubMed] 
27. Aiewsakun, P.; Katzourakis, A. Marine origin of retroviruses in the early Palaeozoic Era. Nat. Commun. 2017, 8, 13954. [CrossRef]

28. Han, G.Z.; Worobey, M. An endogenous foamy-like viral element in the coelacanth genome. PLoS Pathog. 2012, 8, e1002790. [CrossRef]

29. Ruboyianes, R.; Worobey, M. Foamy-like endogenous retroviruses are extensive and abundant in teleosts. Virus Evol. 2016, 2, vew032. [CrossRef]

30. Han, G.Z. Extensive retroviral diversity in shark. Retrovirology 2015, 12, 34. [CrossRef]

31. Aiewsakun, P.; Simmonds, P.; Katzourakis, A. The first co-opted endogenous foamy viruses and the evolutionary history of reptilian foamy viruses. Viruses 2019, 11, 7. [CrossRef]

32. Switzer, W.M.; Salemi, M.; Shanmugam, V.; Gao, F.; Cong, M.E.; Kuiken, C.; Bhullar, V.; Beer, B.E.; Vallet, D.; Gautier-Hion, A.; et al. Ancient co-speciation of simian foamy viruses and primates. Nature 2005, 434, 376-380. [CrossRef] [PubMed]

33. Shankar, A.; Sibley, S.D.; Goldberg, T.L.; Switzer, W.M. Molecular analysis of the complete genome of a simian foamy virus infecting hylobates pileatus (pileated gibbon) reveals ancient co-evolution with lesser apes. Viruses 2019, 11, 605. [CrossRef] [PubMed]

34. Switzer, W.; Shanmugam, J.H.K.V.; Heneine, W. Seroprevalence of human infection with simian foamy virus from new world primates. In Proceedings of the 16th Conference on Retroviruses and Opportunistic Infection, Montreal, QC, Canada, 8-11 February 2009.

35. Mouinga-Ondeme, A.; Betsem, E.; Caron, M.; Makuwa, M.; Salle, B.; Renault, N.; Saib, A.; Telfer, P.; Marx, P.; Gessain, A.; et al. Two distinct variants of simian foamy virus in naturally infected mandrills (Mandrillus sphinx) and cross-species transmission to humans. Retrovirology 2010, 7, 105. [CrossRef] [PubMed]

36. Leendertz, S.A.; Junglen, S.; Hedemann, C.; Goffe, A.; Calvignac, S.; Boesch, C.; Leendertz, F.H. High prevalence, coinfection rate, and genetic diversity of retroviruses in wild red colobus monkeys (Piliocolobus badius badius) in Tai National Park, Cote d'Ivoire. J. Virol. 2010, 84, 7427-7436. [CrossRef] [PubMed]

37. Liu, W.; Worobey, M.; Li, Y.; Keele, B.F.; Bibollet-Ruche, F.; Guo, Y.; Goepfert, P.A.; Santiago, M.L.; Ndjango, J.B.; Neel, C.; et al. Molecular ecology and natural history of simian foamy virus infection in wild-living chimpanzees. PLoS Pathog. 2008, 4, e1000097. [CrossRef]

38. Broussard, S.R.; Comuzzie, A.G.; Leighton, K.L.; Leland, M.M.; Whitehead, E.M.; Allan, J.S. Characterization of new simian foamy viruses from African nonhuman primates. Virology 1997, 237, 349-359. [CrossRef]

39. Huang, F.; Wang, H.; Jing, S.; Zeng, W. Simian foamy virus prevalence in Macaca mulatta and zookeepers. AIDS Res. Hum. Retroviruses 2012, 28, 591-593. [CrossRef]

40. Hood, S.; Mitchell, J.L.; Sethi, M.; Almond, N.M.; Cutler, K.L.; Rose, N.J. Horizontal acquisition and a broad biodistribution typify simian foamy virus infection in a cohort of Macaca fascicularis. Virol. J. 2013, 10, 326. [CrossRef]

41. Calattini, S.; Wanert, F.; Thierry, B.; Schmitt, C.; Bassot, S.; Saib, A.; Herrenschmidt, N.; Gessain, A. Modes of transmission and genetic diversity of foamy viruses in a Macaca tonkeana colony. Retrovirology 2006, 3, 23. [CrossRef]

42. Blewett, E.L.; Black, D.H.; Lerche, N.W.; White, G.; Eberle, R. Simian foamy virus infections in a baboon breeding colony. Virology 2000, 278, 183-193. [CrossRef]

43. Muniz, C.P.; Zheng, H.; Jia, H.; Cavalcante, L.T.F.; Augusto, A.M.; Fedullo, L.P.; Pissinatti, A.; Soares, M.A.; Switzer, W.M.; Santos, A.F. A non-invasive specimen collection method and a novel simian foamy virus (SFV) DNA quantification assay in New World primates reveal aspects of tissue tropism and improved SFV detection. PLoS ONE 2017, 12, e0184251. [CrossRef] [PubMed]

44. Stenbak, C.R.; Craig, K.L.; Ivanov, S.B.; Wang, X.; Soliven, K.C.; Jackson, D.L.; Gutierrez, G.A.; Engel, G.; Jones-Engel, L.; Linial, M.L. New World simian foamy virus infections in vivo and in vitro. J. Virol. 2014, 88, 982-991. [CrossRef] [PubMed]

45. Soliven, K.; Wang, X.; Small, C.T.; Feeroz, M.M.; Lee, E.G.; Craig, K.L.; Hasan, K.; Engel, G.A.; Jones-Engel, L.; Matsen, F.A.; et al. Simian foamy virus infection of rhesus macaques in Bangladesh: Relationship of latent proviruses and transcriptionally active viruses. J. Virol. 2013, 87, 13628-13639. [CrossRef] [PubMed]

46. Murray, S.M.; Picker, L.J.; Axthelm, M.K.; Linial, M.L. Expanded tissue targets for foamy virus replication with simian immunodeficiency virus-induced immunosuppression. J. Virol. 2006, 80, 663-670. [CrossRef] [PubMed] 
47. Falcone, V.; Leupold, J.; Clotten, J.; Urbanyi, E.; Herchenroder, O.; Spatz, W.; Volk, B.; Bohm, N.; Toniolo, A.; Neumann-Haefelin, D.; et al. Sites of simian foamy virus persistence in naturally infected African green monkeys: Latent provirus is ubiquitous, whereas viral replication is restricted to the oral mucosa. Virology 1999, 257, 7-14. [CrossRef]

48. Liu, Y.; Betts, M.J.; Lei, J.; Wei, G.; Bao, Q.; Kehl, T.; Russell, R.B.; Lochelt, M. Mutagenesis of N-terminal residues of feline foamy virus Gag reveals entirely distinct functions during capsid formation, particle assembly, Gag processing and budding. Retrovirology 2016, 13, 57. [CrossRef]

49. Lambert, C.; Couteaudier, M.; Gouzil, J.; Richard, L.; Montange, T.; Betsem, E.; Rua, R.; Tobaly-Tapiero, J.; Lindemann, D.; Njouom, R.; et al. Potent neutralizing antibodies in humans infected with zoonotic simian foamy viruses target conserved epitopes located in the dimorphic domain of the surface envelope protein. PLoS Pathog. 2018, 14, e1007293. [CrossRef]

50. Murray, S.M.; Picker, L.J.; Axthelm, M.K.; Hudkins, K.; Alpers, C.E.; Linial, M.L. Replication in a superficial epithelial cell niche explains the lack of pathogenicity of primate foamy virus infections. J. Virol. 2008, 82, 5981-5985. [CrossRef]

51. Smiley Evans, T.; Barry, P.A.; Gilardi, K.V.; Goldstein, T.; Deere, J.D.; Fike, J.; Yee, J.; Ssebide, B.J.; Karmacharya, D.; Cranfield, M.R.; et al. Optimization of a Novel Non-invasive Oral Sampling Technique for Zoonotic Pathogen Surveillance in Nonhuman Primates. PLoS Negl. Trop. Dis. 2015, 9, e0003813. [CrossRef]

52. Smiley Evans, T.; Gilardi, K.V.; Barry, P.A.; Ssebide, B.J.; Kinani, J.F.; Nizeyimana, F.; Noheri, J.B.; Byarugaba, D.K.; Mudakikwa, A.; Cranfield, M.R.; et al. Detection of viruses using discarded plants from wild mountain gorillas and golden monkeys. Am. J. Primatol. 2016, 78, 1222-1234. [CrossRef]

53. Schweizer, M.; Schleer, H.; Pietrek, M.; Liegibel, J.; Falcone, V.; Neumann-Haefelin, D. Genetic stability of foamy viruses: Long-term study in an African green monkey population. J. Virol. 1999, 73, 9256-9265. [PubMed]

54. Brooks, J.I.; Merks, H.W.; Fournier, J.; Boneva, R.S.; Sandstrom, P.A. Characterization of blood-borne transmission of simian foamy virus. Transfusion 2007, 47, 162-170. [CrossRef] [PubMed]

55. Blasse, A.; Calvignac-Spencer, S.; Merkel, K.; Goffe, A.S.; Boesch, C.; Mundry, R.; Leendertz, F.H. Mother-offspring transmission and age-dependent accumulation of simian foamy virus in wild chimpanzees. J. Virol. 2013, 87, 5193-5204. [CrossRef] [PubMed]

56. VandeWoude, S.; Apetrei, C. Going wild: Lessons from naturally occurring T-lymphotropic lentiviruses. Clin. Microbiol. Rev. 2006, 19, 728-762. [CrossRef]

57. Santiago, M.L.; Range, F.; Keele, B.F.; Li, Y.; Bailes, E.; Bibollet-Ruche, F.; Fruteau, C.; Noe, R.; Peeters, M.; Brookfield, J.F.; et al. Simian immunodeficiency virus infection in free-ranging sooty mangabeys (Cercocebus atys atys) from the Tai Forest, Cote d'Ivoire: Implications for the origin of epidemic human immunodeficiency virus type 2. J. Virol. 2005, 79, 12515-12527. [CrossRef]

58. Choudhary, A.; Galvin, T.A.; Williams, D.K.; Beren, J.; Bryant, M.A.; Khan, A.S. Influence of naturally occurring simian foamy viruses (SFVs) on SIV disease progression in the rhesus macaque (Macaca mulatta) model. Viruses 2013, 5, 1414-1430. [CrossRef]

59. Leendertz, F.H.; Zirkel, F.; Couacy-Hymann, E.; Ellerbrok, H.; Morozov, V.A.; Pauli, G.; Hedemann, C.; Formenty, P.; Jensen, S.A.; Boesch, C.; et al. Interspecies transmission of simian foamy virus in a natural predator-prey system. J. Virol. 2008, 82, 7741-7744. [CrossRef]

60. Betsem, E.; Rua, R.; Tortevoye, P.; Froment, A.; Gessain, A. Frequent and recent human acquisition of simian foamy viruses through apes' bites in central Africa. PLoS Pathog. 2011, 7, e1002306. [CrossRef]

61. Jones-Engel, L.; May, C.C.; Engel, G.A.; Steinkraus, K.A.; Schillaci, M.A.; Fuentes, A.; Rompis, A.; Chalise, M.K.; Aggimarangsee, N.; Feeroz, M.M.; et al. Diverse contexts of zoonotic transmission of simian foamy viruses in Asia. Emerg. Infect. Dis. 2008, 14, 1200-1208. [CrossRef]

62. Khan, A.S. Simian foamy virus infection in humans: Prevalence and management. Exp. Rev. Anti Infect. Ther. 2009, 7, 569-580. [CrossRef]

63. Switzer, W.M.; Bhullar, V.; Shanmugam, V.; Cong, M.E.; Parekh, B.; Lerche, N.W.; Yee, J.L.; Ely, J.J.; Boneva, R.; Chapman, L.E.; et al. Frequent simian foamy virus infection in persons occupationally exposed to nonhuman primates. J. Virol. 2004, 78, 2780-2789. [CrossRef] [PubMed]

64. Switzer, W.M.H. Foamy virus infection of humans. In Molecular Detection of Human Viral Pathogens; Liu, D., Ed.; CRC Press: Boca Raton, FL, USA, 2011. 
65. Pinto-Santini, D.M.; Stenbak, C.R.; Linial, M.L. Foamy virus zoonotic infections. Retrovirology 2017, 14, 55. [CrossRef] [PubMed]

66. Brooks, J.I.; Rud, E.W.; Pilon, R.G.; Smith, J.M.; Switzer, W.M.; Sandstrom, P.A. Cross-species retroviral transmission from macaques to human beings. Lancet 2002, 360, 387-388. [CrossRef]

67. Wolfe, N.D.; Switzer, W.M.; Carr, J.K.; Bhullar, V.B.; Shanmugam, V.; Tamoufe, U.; Prosser, A.T.; Torimiro, J.N.; Wright, A.; Mpoudi-Ngole, E.; et al. Naturally acquired simian retrovirus infections in central African hunters. Lancet 2004, 363, 932-937. [CrossRef]

68. Calattini, S.; Betsem, E.B.; Froment, A.; Mauclere, P.; Tortevoye, P.; Schmitt, C.; Njouom, R.; Saib, A.; Gessain, A. Simian foamy virus transmission from apes to humans, rural Cameroon. Emerg. Infect. Dis. 2007, 13, 1314-1320. [CrossRef]

69. Switzer, W.M.; Tang, S.; Ahuka-Mundeke, S.; Shankar, A.; Hanson, D.L.; Zheng, H.; Ayouba, A.; Wolfe, N.D.; LeBreton, M.; Djoko, C.F.; et al. Novel simian foamy virus infections from multiple monkey species in women from the Democratic Republic of Congo. Retrovirology 2012, 9, 100. [CrossRef]

70. Mouinga-Ondeme, A.; Caron, M.; Nkoghe, D.; Telfer, P.; Marx, P.; Saib, A.; Leroy, E.; Gonzalez, J.P.; Gessain, A.; Kazanji, M. Cross-species transmission of simian foamy virus to humans in rural Gabon, Central Africa. J. Virol. 2012, 86, 1255-1260. [CrossRef]

(C) 2019 by the authors. Licensee MDPI, Basel, Switzerland. This article is an open access article distributed under the terms and conditions of the Creative Commons Attribution (CC BY) license (http://creativecommons.org/licenses/by/4.0/). 